\title{
Comparative Analysis of Static Bending Test and Constitutive Modeling of Simarouba amara Aubl. Wood Specie
}

\author{
Vinicius Borges de Moura Aquino ${ }^{1}$, Krisman Engelbrecht Desto ${ }^{1}$, Marco Donisete de Campos ${ }^{2}$, \\ Eduardo Chahud ${ }^{3}$, André Luis Christoforo ${ }^{1, *}$, Francisco Antonio Rocco Lahr ${ }^{4}$ \\ ${ }^{1}$ Centre for Innovation and Technology in Composites - CITeC, Department of Civil Engineering (DECiv), Federal University of São \\ Carlos, São Carlos, Brazil \\ ${ }^{2}$ Earth and Exacts Sciences Institute (ICET), Federal University of Mato Grosso, Barra do Garças, Mato Grosso, Brazil \\ ${ }^{3}$ Department of Civil Engineering, Federal University of Minas Gerais (UFMG), Belo Horizonte, Brazil \\ ${ }^{4}$ Department of Structural Engineering (SET), University of Sao Paulo, São Carlos, Brazil
}

\begin{abstract}
The three point bending test, according the Brazilian Standard ABNT NBR 7190, enables to identify the values of two wood properties: conventional modulus of elasticity and conventional strength on static bending test. With the results, this study aimed to perform a numerical simulation using the finite element software ABAQUS and the experimental results of three point bending test using Simarouba amara Aubl wood specie test proofs. Two analysis were performed, considering wood as elastoplastic material in the first and the second, considering only elastic material. From stress-strain diagrams results, it was observed the evaluation of modulus of elasticity on static bending test is not valid due to material non-linearity. A constitutive model was proposed for Simarouba amara Aubl. wood specie and for evaluation of modulus of elasticity on static bending. It was performed a comparative analysis between experimental results and the proposed constitutive model. These models showed their efficiency when evaluated the normal stress on proof test with demonstrated accuracy, allowing its use by wood structures designers.
\end{abstract}

Keywords Comparative Analysis, Three Point Bending Test, Wood, Numerical Modeling, Caixeta, Simarouba amara Aubl., Constitutive Model

\section{Introduction}

Wood is widely used as the main material in civil construction due its thermal performance and esthetics [1]. Among ordinary materials of civil construction, wood can be highlighted, a renewable resource with low energy consumption in its production $[2,3]$.

The knowledge of physical and mechanical properties leads to an efficient use of material, mainly in structural design. Then, wood must be properly analyzed by its great variability of properties when compared with other materials and large variety of wood species [4].

The relations between stress and strain and elastic parameters of wood are very important for the mathematical modeling of its structural behavior [5].

* Corresponding author:

alchristoforo@gmail.com (André Luis Christoforo)

Published online at http://journal.sapub.org/ijme

Copyright (C) 2018 The Author(s). Published by Scientific \& Academic Publishing This work is licensed under the Creative Commons Attribution International

License (CC BY). http://creativecommons.org/licenses/by/4.0/
There are several tests to determine wood properties as apparent density and shrinkage. Mechanical tests are applied to simulate wood in real use as conventional strength on static bending test and compressive and tensile strength parallel to the grain. It must be pointed out that exotic wood species produced in Brazil presents different physical and mechanical properties when compared with properties in native country of wood specie $[6,7]$.

In the mechanical characterization of woods it is common the use of displacement parameter to evaluate the loading cycle to determine the conventional modulus of elasticity on static bending test [8]. Then, it is important to know if this displacement parameters are compatible with the procedure described in the Brazilian Standard ABNT NBR 7190 [9].

Other authors [10-12] studied the modulus of elasticity in wood. Among them, Chahud [12] proposed a new evaluation of normal stress on static bending test along the grain, considering the plastic regime in wood and comparing the moduli of elasticity in tension, compression and on static bending test.

Considering the importance of elasticity modulus in wood structures design, the form of its analysis and determination 
in laboratories throughout the years have improved, leading to a more reliable wood property for designers of wood structures when considering the effect of buckling in wood columns and measuring the vertical displacement in wood beams [13-15].

For this reason, the present research intend to perform a numerical comparation with the conventional three point static bending test experiment performed by Almeida et al. [8] to verify the significance to model Simarouba amara $A u b l$. wood, an orthotropic material, as isotropic material, according Brazilian Standard ABNT NBR 7190 [9] and propose a constitutive model for Simarouba amara Aubl. wood specie.

\section{Material and Methods}

Experimental tests were made using 18 test proofs with nominal dimensions 20x20x320 mm [8] using wood around $12 \%$ moisture, with the major dimension parallel to the grain.

Although the relation length/height disposed by the Brazilian Standard ABNT NBR 7190 [9] is 21, the test proofs were made with ratio length/height equal 14, due to universal machine EMIC is unable to develop tests with proofs longer than $320 \mathrm{~mm}$.

For an appropriate comparation, the numerical modeling was made using the nominal dimensions of 20x20x320 mm, following the ratio length/height equal to 14 .

The modulus of elasticity on static bending test and the strength on static bending test were obtained according the disposed in Annex $B$ in the Brazilian Standard ABNT NBR 7190 [9]. The analysis performed considered the three point bending test (Figure 1).

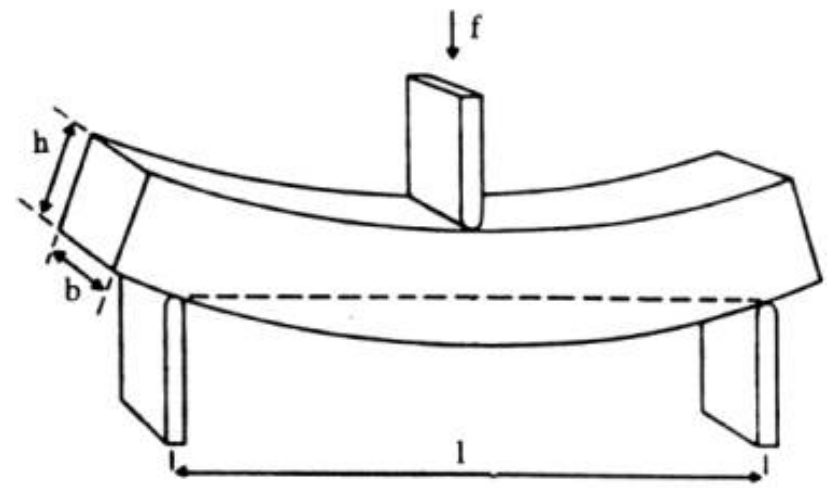

Figure 1. Scheme of Three Point Bending Test. Source: https://www.poliuretanos.com.br/Cap8/8125Compressao.htm

Despite the fact that wood is considered an orthotropic material, numerical modeling considered the material isotropic. This modification was evaluated in the final results to verify the significance of this consideration in the final associated error.

The numerical modeling used finite element analysis software ABAQUS. ABAQUS/CAE provides a pre-processing and post-processing interface (Figure 2) for model analysis [16]. Widely used in automotive and aerospace industries, it is used for academic purpose due its capacity to solve non-linear problems.

With modeling executed in software ABAQUS, proceed the discretization of the area in finite elements. The discretization was made using a 3D element S8R, Shell Planar, with partitions to apply boundary conditions and a four layer mesh (Figure 3).

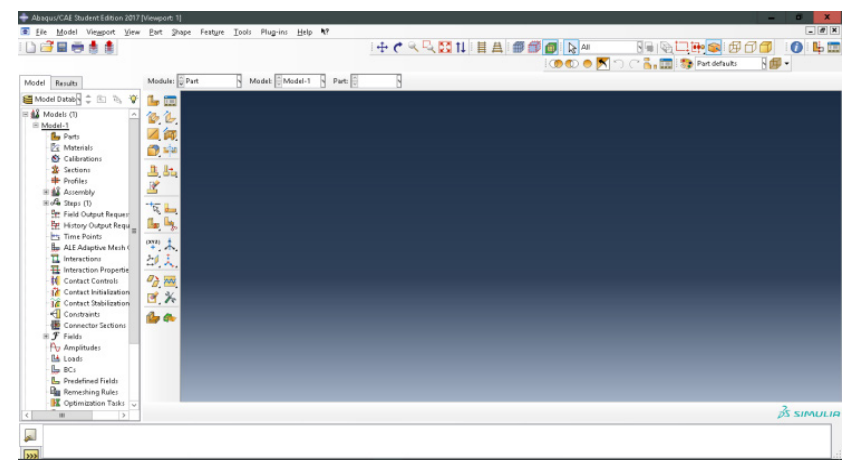

Figure 2. ABAQUS Interface (Source: Author)

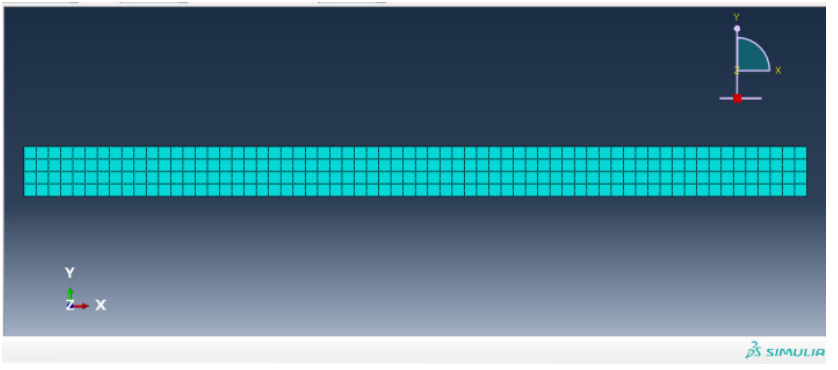

Figure 3. Mesh discretization (Source: Author)

The material was considered linear elastic in the Analysis 1 considering plastic deformation in wood. In Analysis 2, the material will be considered only in elastic regime. These analysis will be done using the conventional modulus of elasticity on static bending test, $\mathrm{E}_{\mathrm{M}}$, defined by Brazilian Standard ABNT NBR 7190 [9] using the average values obtained by Almeida et al. [8] in force displacement diagram. The Poisson coefficient to be used is an estimative made by Ballarin and Nogueira [5] for hardwood species in radial longitudinal plan, which one will be solicited in the proof test, equal to $v_{\mathrm{LR}}=0.37$. These considerations were made due to lack of literature about physical and mechanical characterization of Simarouba amara Aubl wood specie.

\subsection{Numerical Validation}

The computational validation in this research used the results of Mello and Castanheira [17], a cantilever and pinned beam and the results of Liu and Quek [18], a cantilever beam. To validate the numerical analysis in this research, models were created in ABAQUS software to perform the same analysis made by Mello and Castanheira [17] and Liu and Quek [18] and analyze the associated error between the ABAQUS results (Present Research) and the author's results $[17,18]$. 
Mello and Castanheira [17] cantilever and pinned beam (Figure 4) has the modulus of elasticity $\mathrm{E}=200 \mathrm{GPa}$; Poisson's coefficient $v=0.3$; cross section inertia moment I $=1.180 \mathrm{E}-4 \mathrm{~m}^{4}$.

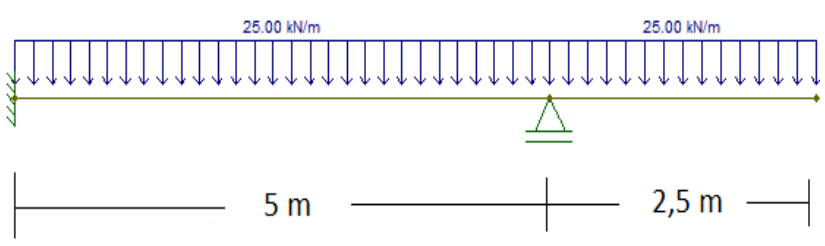

Figure 4. Cantilever and pinned beam (Source: Author)

In Mello and Castanheira [17] the load was distributed along the beam. For the results, it was uses quadrangular elements of $0.097 \mathrm{~m}$. For each element, it followed the modeling already described. Imposing the boundary conditions, the vertical displacement (Figure 5) is presented. Also the comparation between the Mello and Castanheira [17] result and this study result is presented (Figure 6).

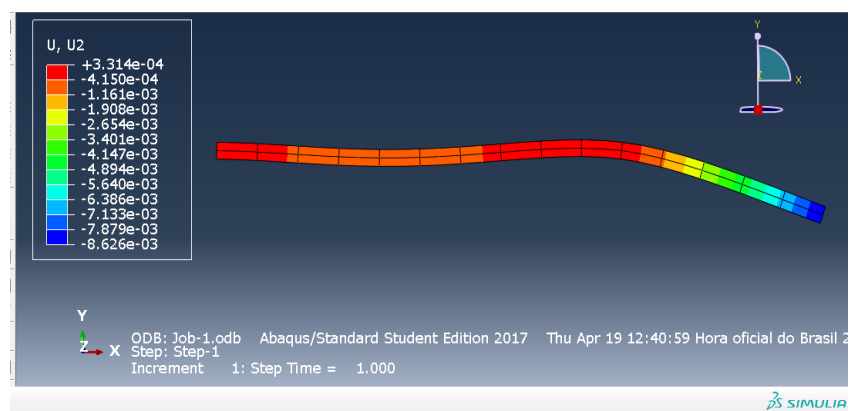

Figure 5. Vertical Displacement (Source: Author)

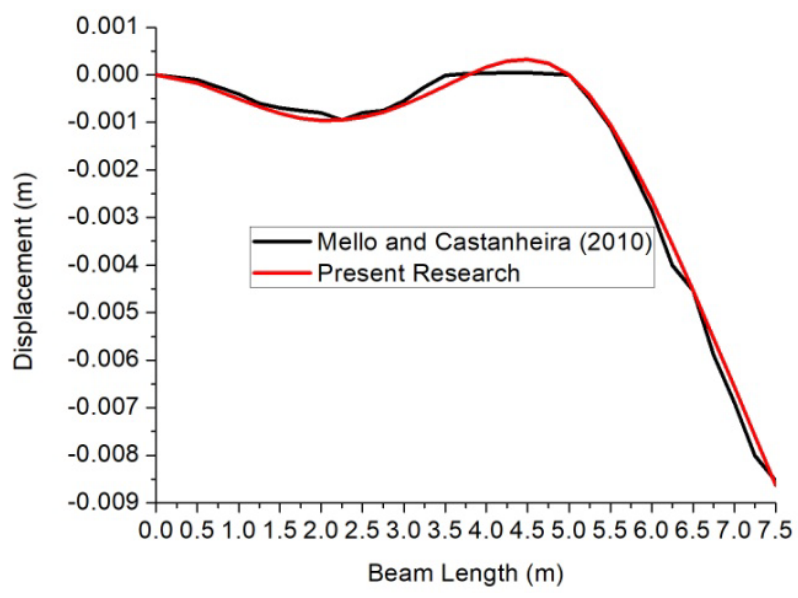

Figure 6. Comparative analysis between models (Source: Author)

The average quadratic error proposed by Lichten [19] was calculated to evaluate the associated error:

$$
\varepsilon=\sqrt{(1 /(n+1)) \sum_{i=1}^{n+1} \varepsilon_{i}^{2}}
$$

With $\varepsilon=d_{i}-d_{i}^{*}, d_{i}$ being the numerical solution, $d_{i}^{*}$ the displacement and $n$ the number of discretization points, presented in Table 1.
Table 1. Average Quadratic Error

\begin{tabular}{cc}
\hline Number of points & Average Quadratic Error (\&) \\
\hline 28 & $1.83 \mathrm{E}-08$ \\
\hline
\end{tabular}

The Liu and Quek [18] cantilever beam (Figure 7) has the modulus of elasticity $\mathrm{E}=69 \mathrm{GPa}$; Poisson's coefficient $v=$ 0.3 ; cross section inertia moment $\mathrm{I}=1.80 \mathrm{E}-6 \mathrm{~m}^{4} ; 1000 \mathrm{~N}$ point load.

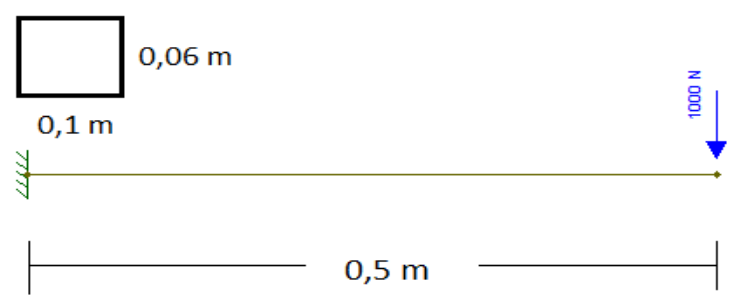

Figure 7. Cantilever beam detailing (Source: Author)

In Liu and Quek [12] the load was distributed along the beam. For the results, it were used quadrangular elements of $0.05 \mathrm{~m}$. For each element, it followed the modeling had already described. Imposing the boundary conditions, the vertical displacement (Figure 8) is presented.

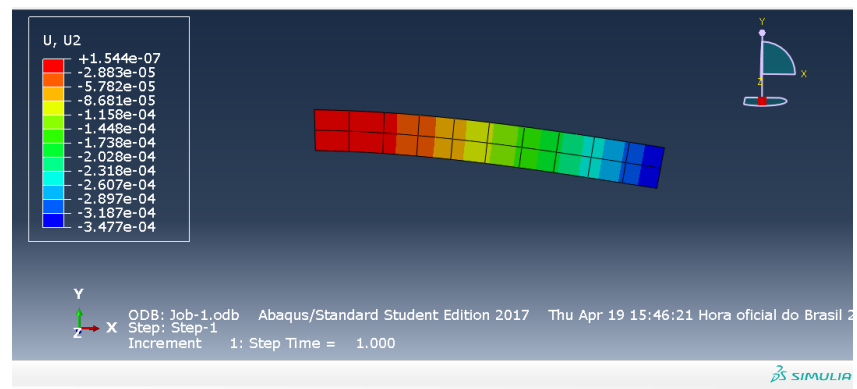

Figure 8. Vertical Displacement (Source: Author)

Table 2. Displacement in Liu and Quek [12] and Present Research

\begin{tabular}{ccc}
\hline Beam length (m) & Liu and Quek [12] & Present Research \\
\hline 0.00 & 0.00 & $-1.127 \mathrm{E}-33$ \\
0.25 & $-1.048 \mathrm{E}-04$ & $-1.107 \mathrm{E}-04$ \\
0.50 & $-3.355 \mathrm{E}-04$ & $-3.471 \mathrm{E}-04$ \\
\hline
\end{tabular}

Table 3 displays the average quadratic error for displacements in Liu and Quek [18] and the present research.

Table 3. Average Quadratic Error

\begin{tabular}{cc}
\hline Number of Points & Average Quadratic Error $(\boldsymbol{\varepsilon})$ \\
\hline 3 & $2.92 \mathrm{E}-08$ \\
\hline
\end{tabular}

\section{Results and Discussion}

In this section, the ultimate tensile stress parallel to the grain $\left(\sigma_{x}\right)$ and the maximum vertical displacement in the beam will be evaluated.

For modeling, the boundary conditions and the material constants like the ultimate load on the beam, the modulus of elasticity and Poisson's coefficient were inserted in 


\section{ABAQUS software.}

Considering the study of Almeida et al. [8] the load-displacement diagram is presented with average values (Figure 9).

With load-displacement diagram, the conventional modulus of elasticity on static bending test, $\mathrm{E}_{\mathrm{M}}$ is presented on Eq. (2), according the disposed in the Annex $B$ of the Brazilian Standard ABNT NBR 7190 [9]. The average ultimate load of rupture found was $1139.54 \mathrm{~N}$.

$$
E_{M}=\frac{\left(F_{M, 50 \%}-F_{M, 10 \%}\right) L^{3}}{\left(v_{50 \%}-v_{10 \%}\right) 4 b h^{3}}
$$

The $\mathrm{F}_{\mathrm{M}, 50 \%}, \mathrm{~F}_{\mathrm{M}, 10 \%}$ and $\mathrm{v}_{50 \%}, \mathrm{v}_{10 \%}$ represents the force and displacement on $50 \%$ and $10 \%$ of ultimate load of rupture, respectively. Then, according to the load-displacement diagram (Figure 9), $\mathrm{F}_{\mathrm{M}, 50 \%}$ equals to $569.77 \mathrm{~N}$ and $\mathrm{F}_{\mathrm{M}, 10 \%}$ equals to $113.95 \mathrm{~N}$. The displacement $\mathrm{v}_{50}$ equals to 3.20 $\mathrm{mm}$ and $\mathrm{v}_{10 \%}$ equals to $0.62 \mathrm{~mm}$.

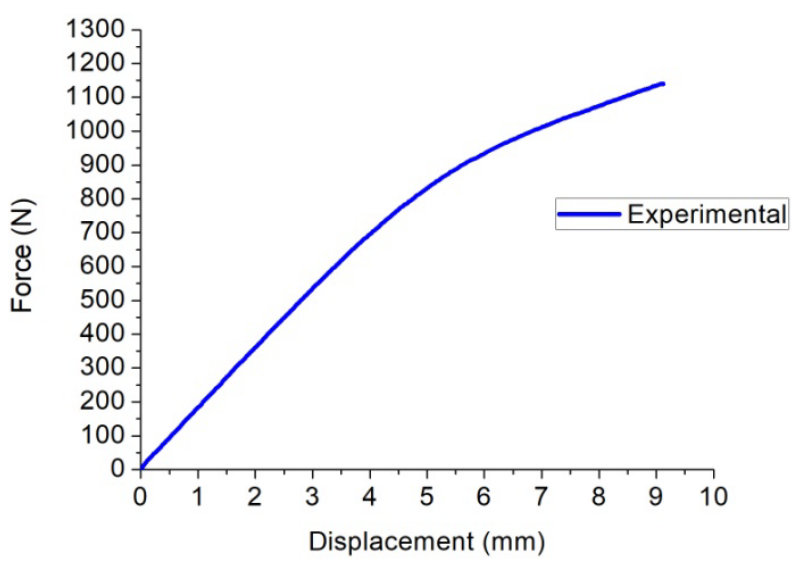

Figure 9. Average Load-Displacement Diagram on Three Point Bending Test (Source: Author)

Performing the substitutions in Eq. 2, the average $\mathrm{E}_{\mathrm{M}}$ for Simarouba amara Aubl. equals to $6418.89 \mathrm{MPa}$. To determine the conventional strength on static bending test $\left(f_{M}\right)$, defined by:

$$
f_{M}=\frac{M_{m \llbracket x}}{W_{e}}
$$

The $\mathrm{W}_{\mathrm{e}}$ is the elastic modulus section and $\mathrm{M}_{\max }$ the maximum couple applied. Substituting the values in Eq. (3), the $\mathrm{f}_{\mathrm{M}}$ equals to $59.82 \mathrm{MPa}$ for Simarouba amara Aubl. wood specie.

In the Analysis 1 the material will be considered as elastoplastic material. The plastic regime was calculated according the percentage of the elastic loading about the ultimate load. According Almeida et al [8], the average percentage is $78.51 \%$ of the ultimate load $(1139.54 \mathrm{~N})$. Then, the elastic normal stress on bending $\left(f_{\mathrm{MEI}}\right)$ was calculated with this load. The plastic strain was estimated based in the conventional strength $f_{M}$ and the ultimate elastic normal stress $\mathrm{f}_{\mathrm{MEl}}$ using the elastic theory, the Hooke's law [20]. This estimative was made in this form due to lack of mathematical modeling in literature dealing with this type of strain in wood. Thereby, the stress-strain diagram was evaluated for Simarouba amara Aubl. wood specie. The real stress in the beam and plastic strain were calculated (Table 4) for Analysis 1.

Table 4. Evaluation of Real Stress and Plastic Strain

\begin{tabular}{ccccc}
\hline $\begin{array}{c}\text { Nominal } \\
\text { Stress }\left(\mathbf{N} / \mathbf{c m}^{2}\right)\end{array}$ & $\begin{array}{c}\text { Nominal } \\
\text { Strain }\end{array}$ & $\begin{array}{c}\text { Real Stress } \\
\left(\mathbf{N} / \mathbf{c m}^{2}\right)\end{array}$ & $\begin{array}{c}\text { Real } \\
\text { Strain }\end{array}$ & $\begin{array}{c}\text { Plastic } \\
\text { Strain }\end{array}$ \\
\hline 4260.30 & 0.00639 & 4283 & 0.00637 & 0.0000 \\
5980.00 & 0.00899 & 6036 & 0.00894 & 0.0001 \\
\hline
\end{tabular}

The presented values of normal stress are in $\mathrm{N} / \mathrm{cm}^{2}$ and the displacement values are in centimeters. Thus, the results for normal stress are disposed (Figure 10).

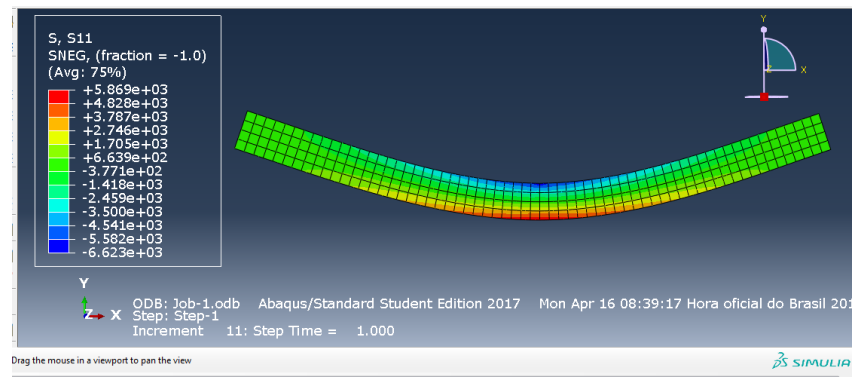

Figure 10. Normal Stress along the Fibers - Elastoplastic Analysis (Source: Author)

In addition, the result for vertical displacement is showed (Figure 11).

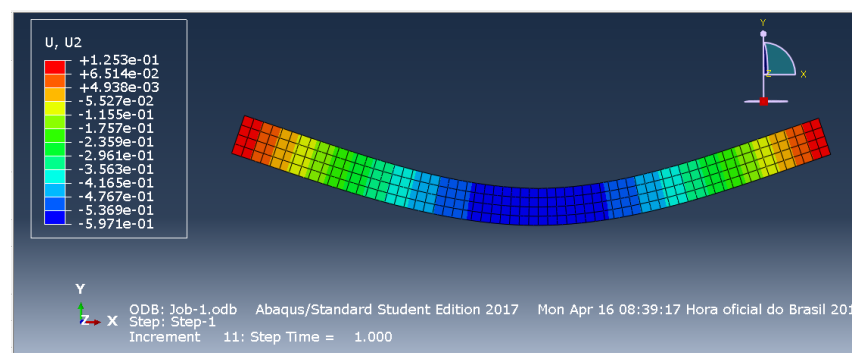

Figure 11. Vertical displacement - Elastoplastic analysis (Source: Author)

For Analysis 2, the material was considered in elastic regime. The applied load considered is the ultimate load [1139.54 N]. Then, the results for normal stress along the grain (Figure 12) and vertical displacement (Figure 13) are presented.

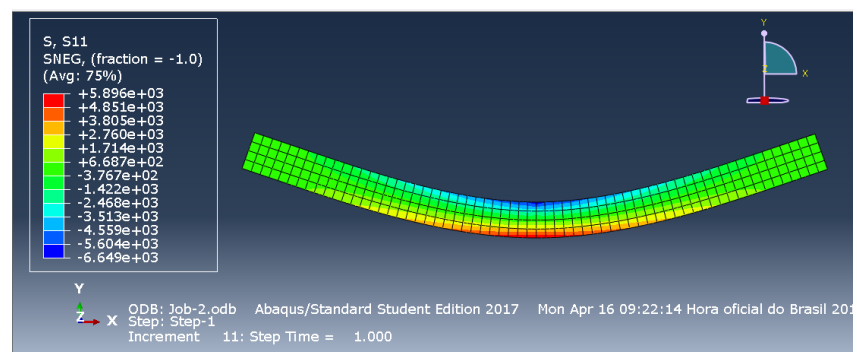

Figure 12. Normal Stress along the Grain - Elastic Analysis (Source: Author) 


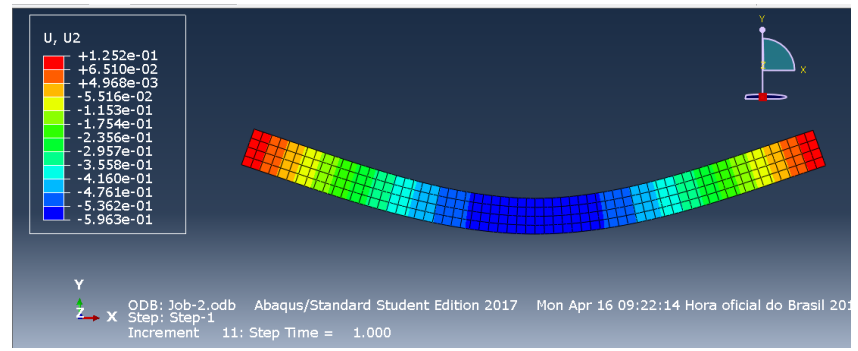

Figure 13. Vertical Displacement - Elastic Analysis (Source: Author)

Considering the numerical and experimental analysis, it is compared the Load-Displacement Diagram in both analysis (Figure 14).

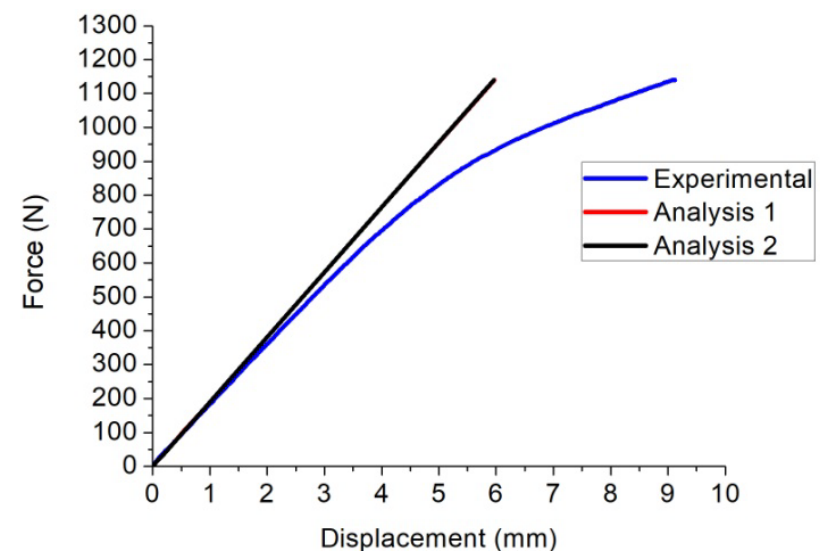

Figure 14. Load-Displacement Diagram - Comparative Analysis (Source: Author)

Observing the load-displacement diagram, it can be inferred the conventional modulus of elasticity in static bending test is not valid due to the curves are not coincident in the stretch equal to $10 \%$ and $50 \%$ of ultimate load. It must be pointed out that Analysis 1 has a small plastic deformation, the material behavior resembles the material behavior in Analysis 2, leading to line overlap in Figure 14.

After the application of $30 \%$ ultimate load, the consideration of elastic material expires, with the experimental curve displaying a considerable displacement. Then, in the evaluation of conventional strength on static bending test must considered a model which includes the inelastic stretch.

For the inelastic stretch, guided by ABAQUS software, it is proposed a stress-strain diagram to evaluate this physical non-linearity.

The model for stress-strain diagram of Simarouba amara Aubl. wood specie was made in an iterative form on ABAQUS, following the behavior of the material in experimental test. In this proposition, the elastic theory was used [20] in the iterations. After that, many models were used to converge to the experimental load-displacement diagram [8]. The considerations made about the material are disposed in Table 5. The modulus of elasticity $\left(\mathrm{E}_{\mathrm{M}}\right)$ was calculated using the formula disposed in ABNT NBR 7190 [9], but using the percentages of $10 \%$ and $30 \%$ of ultimate load in values of load and displacement, respectively. Thus, by the load-displacement diagram, $\mathrm{F}_{\mathrm{M}, 30 \%}$ equals to $341.86 \mathrm{~N}$ and $\mathrm{F}_{\mathrm{M}, 10 \%}$ equals to $113.95 \mathrm{~N}$. The displacement $\mathrm{v}_{50 \%}$ equals to $1.89 \mathrm{~mm}$ and $\mathrm{v}_{10 \%}$ equals to $0.62 \mathrm{~mm}$. Performing the substitutions in Eq. (2), the new $\mathrm{E}_{\mathrm{M}}$ for Simarouba amara Aubl. is 6155.42 MPa. Poisson's coefficient is the same evaluated by Ballarin and Nogueira [5]. The plastic analysis followed the previous one, evaluating the real stress and plastic strain.

Table 5. Evaluation of Real Stress and Plastic Strain

\begin{tabular}{ccccc}
\hline $\begin{array}{c}\text { Nominal Stress } \\
\left(\mathbf{N} / \mathbf{c m}^{2}\right)\end{array}$ & $\begin{array}{c}\text { Nominal } \\
\text { Strain }\end{array}$ & $\begin{array}{c}\text { Real Stress } \\
\left(\mathbf{N} / \mathbf{c m}^{2}\right)\end{array}$ & $\begin{array}{c}\text { Real } \\
\text { Strain }\end{array}$ & $\begin{array}{c}\text { Plastic } \\
\text { Strain }\end{array}$ \\
\hline 2490.00 & 0.0040452 & 2500.07 & 0.00 & 0.0000 \\
3466.00 & 0.0085952 & 3495.79 & 0.01 & 0.0029 \\
4200.00 & 0.0119952 & 4250.38 & 0.01 & 0.0050 \\
4436.00 & 0.0145252 & 4500.43 & 0.01 & 0.0071 \\
4670.50 & 0.0170252 & 4750.02 & 0.02 & 0.0092 \\
5153.00 & 0.0189252 & 5250.52 & 0.02 & 0.0102 \\
5860.00 & 0.0208252 & 5982.04 & 0.02 & 0.0109 \\
\hline
\end{tabular}

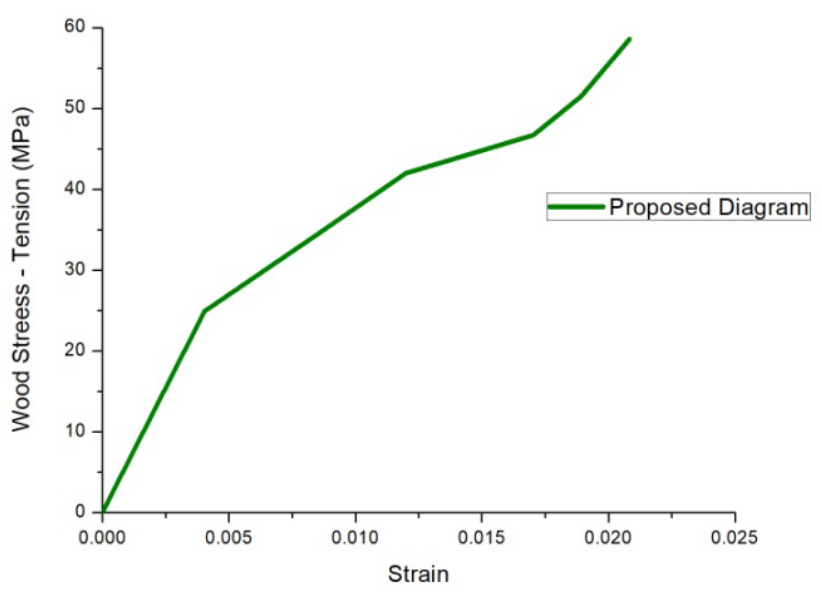

Figure 15. Stress-Strain Diagram - Constitutive Proposed Model for Simarouba amara Aubl. wood specie

After these considerations, the software ABAQUS processed the model. Vertical displacement (Figure 16) and normal stress along the grain (Figure 17) were evaluated.

For comparison, the constitutive model stress-strain proposed diagram and the ABAQUS provided stress-strain diagram is disposed (Figure 18). Also, the experimental load-displacement diagram and the ABAQUS provided load-displacement diagram are compared (Figure 19).

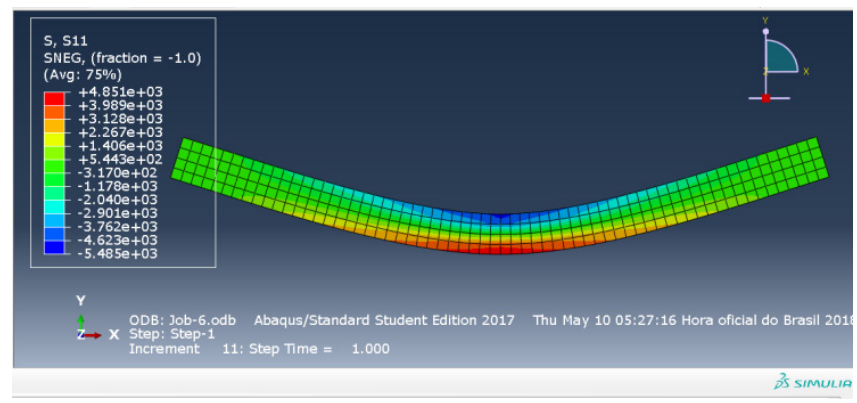

Figure 16. Normal Stress - Constitutive Proposed Model 


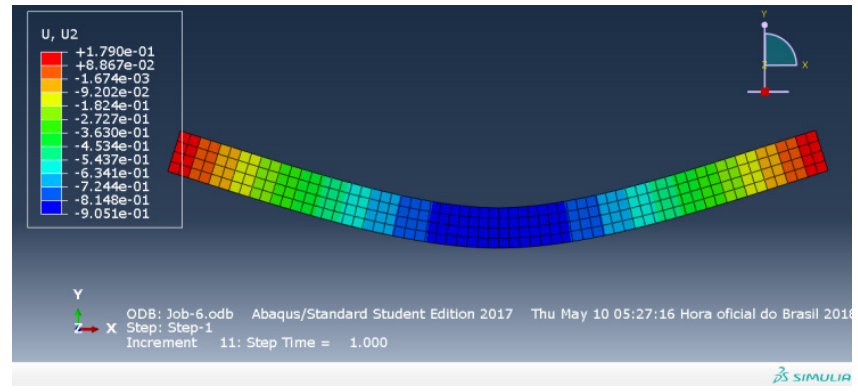

Figure 17. Vertical Displacement - Constitutive Proposed Model

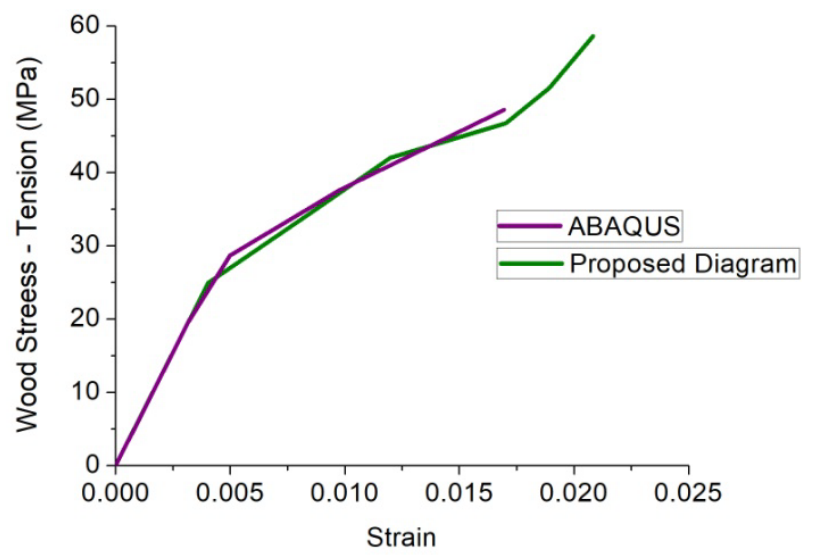

Figure 18. Stress-Strain Diagram - Proposed Diagram and ABAQUS Comparative Analysis

Considering the Figure 18, the constitutive proposed model was appropriated for Simarouba amara Aubl., with the curves displaying good implementation of constitutive model. The software ABAQUS curve shows the material behavior until ultimate strength, obtained in the experimental test [8]. Then, the final stretch on proposed diagram stress-strain diagram is not significative due its rupture in experimental test.

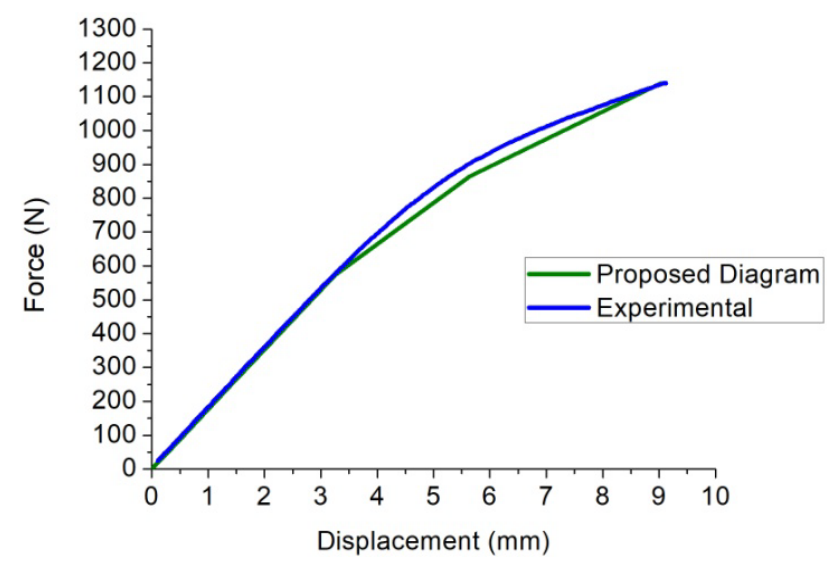

Figure 19. Load Displacement Diagram - Comparative Analysis Constitutive Proposed Model

Observing the Figure 19, the experimental curve and the proposed constitutive model curve are coincident in the elastic regime and very close in the inelastic regime, demonstrating the efficiency of the proposed model.

Considering the fact that Simarouba amara Aubl. wood specie has not been characterized, the constitutive model proposed in this research enables designers of wood structures to use this important and reliable tool to perform the pre dimensioning of wood structures.

The improvement on evaluation and analysis of strength and stiffness properties leads for some standard reviews. Observing the study performed by Logsdon et al. [21], the need of a review is indicated on the Brazilian Standard ABNT NBR 7190 [9]. The calculus model for conventional modulus of elasticity on static bending test $\left(\mathrm{E}_{\mathrm{M}}\right)$ disposed in Brazilian Standard ABNT NBR 7190 [9] was not appropriate for Simarouba amara Aubl. wood specie. As a suggestion for further revisions and researches, an evaluation of percentages of ultimate load to proceed the calculus of $E_{M}$ and the model adopted in this research is suggested.

\section{Conclusions}

The results of this study allow us to conclude:

- A constitutive model was proposed for stress-strain diagram of Simarouba amara Aubl. wood specie. The model showed its efficiency when evaluated the normal stress on proof tests, allowing its use for wood structures designers;

- The numerical validation presented low values of error, demonstrating its accuracy when compared with experimental results;

- The consideration of elastic material to evaluate the conventional modulus of elasticity on static bending test $\left(\mathrm{E}_{\mathrm{M}}\right)$ disposed on Brazilian Standard is not valid due to the material non-linearity;

- The conventional strength on static bending test demands a revision on the Brazilian Standard by cause of material non-linearity on the experiment final stretch, leading to different values.

\section{ACKNOWLEDGMENTS}

For all the provided support, the authors thanks the Coordenação de Aperfeiçoamento de Nível Superior (CAPES) and the Conselho Nacional de Desenvolvimento Científico e Tecnológico (CNPq).

\section{REFERENCES}

[1] Kouroussis, G.; Fekih, L. B.; Descamps, T. Using experimental modal analysis to assess the behaviour of timber elements. Mechanics \& Industry 18, n.804, 2017.

[2] Soriano, J.; Mascia, N. T. Estruturas mistas em concreto-madeira: uma técnica racional para pontes de estradas vicinais. Ciência Rural, v.39, n.4, p.1260-1269, 2009.

[3] Christoforo, A. L.; Panzera, T. H.; Batista, F. B.; Borges, P. H. 
R.; Lahr, F.A.R. Numerical Evaluation of the Modulus of Longitudinal Elasticity in Structural Round Timber Elements of the Eucaliptus genus. Journal of the Brazilian Association of Agricultural Engineering, Jaboticabal-SP, v.31, n.5, p. 1007-1014, set/out, 2011.

[4] Lisboa, C. D. J.; Matos, J. L. M.; Melo, J. E. Amostragem e Propriedades Físico-Mecânicas de Madeiras Amazônicas. Ministério do Meio Ambiente e da Amazônia Legal. Brasília: IBAMA, 1993. 103 p (Coleção Meio Ambiente. Série Estudos Floresta, 1).

[5] Ballarin, A. W.; Nogueira, M. Caracterização Elástica da Madeira de Eucaliptus citriodora. CERNE, v. 9, n. 1, p. 066-080, 2003.

[6] Beltrame, R.; Souza, J. T. de; Machado, W. G.; Vivian, M. A.; Buligon, E. A.; Pauleski, D. T.; Gatto, D. A.; Haselein, C. R. Propriedades físico-mecânicas da madeira de Araucaria angustifolia (Bertol.) em três estratos fitossociológicos, Ciência da Madeira, Pelotas - RS, v. 01, n. 02, p. 54-69, 2010.

[7] Vital, B. R.; Della Lucia, R. M. Características físicas e mecânicas da madeira de Eucalyptus grandis W. Hill ex Maiden. Revista Árvore. v. 4, n. 1, p. 70 - 74, 1980.

[8] Almeida, T. H.; Almeida, D. H.; Christoforo, A. L.; Lahr, F. A. R. Static Bending Loading Diagram in Wood. International Journal of Materials Engineering 2018, 8(1): $1-4$.

[9] Associação Brasileira De Normas Técnicas - ABNT. NBR 7190. Projeto de estruturas de madeira. Rio de Janeiro, 107 p., 1997.

[10] Lara Pinto, M. "Flexão em Peças de Madeira," M. Eng. dissertation, University of São Paulo, São Carlos, Brazil, 1983.

[11] Zakic, B. D.; Inelastic Bending of Wood Beams. Journal of the Structural Division, American Society of Testing
Materials, v. 99, n. 10, p. 2079-2095, oct. 1973.

[12] Chahud, E. "Madeira: Módulo de Elasticidade Longitudinal e Proposta para o Cálculo de Peças Fletidas," M. Eng. thesis, University of São Paulo, São Carlos, Brazil, May. 1989.

[13] Lahr, F. A. R.. "Sobre a Determinação de Propriedades de Elasticidade da Madeira," M. Eng. thesis, University of São Paulo, São Carlos, Brazil, 1983.

[14] Xiao, Q.; Doudak, G.; Mohareb, M. Numerical and experimental investigation of lateral torsional buckling of wood beams. Engineering Structures, v. 151, p. 85-92, 2017.

[15] Machado, J. S.; Louzada, J. L.; Santos, A. J. A.; Nunes, L.; Anjos, O.; Rodrigues, J.; Simões, R. M. S.; Pereira, H. Variation of wood density and mechanical properties of blackwood (Acacia menaloxylon R. Br.) Materials and Design, v. 56, p. 975-980, 2013.

[16] Manjunath, M. Finite-Element Project ABAQUS Tutorial. Institut für Mechanik. Berlin, 2009.

[17] Mello, F. M.; Castanheira, P. Elementos Finitos - Fomulação Residual de Galerkin - Uma introdução com aplicações. Lisboa: Sílabo, 2010.

[18] Liu, G.R.; Quek, S.S. The Finite Element Method - A Practical Course. Burlington: Elsevier, 2003.

[19] Lichten, W. Data and Error Analysis. New York: Prentice-Hall, 1999.

[20] Beer, F. P.; Johnston, E. R.; DeWolf, J. T; Mazurek, D. F. Mechanical of Materials. New York: McGraw-Hill, 2012.

[21] Logsdon, N. B.; Finger, Z.; Estevão, J. G. Descrição Dendrológica e caracterização físico-mecânica da madeira de Amescla-aroeira, Protium heptaphyllum (Aubl) March. (Burseraceae), Revista Madeira Arquitetura e Engenharia, ano 6, Set-Dez. 2005. 